\title{
Contribution of Balance and Explosive Power of Leg Muscles Towards Ability of Jump Shoot of the Athletes at Sport Science Faculty of Padang State University
}

\author{
$\mathrm{R}$ Yenes
}

\author{
Faculty of Sports Science, Universitas Negeri Padang, Indonesia \\ "Corresponding author. Email: ryenes@yahoo.com
}

\begin{abstract}
The problem of this research is the low ability of jump shoot, owned by basketball athletes of Sport Science Faculty of Padang State University. Therefore, some factors that affect the ability of jump shoot of basketball athletes were investigated. In this research, the researcher found the factor of balance and explosive power of leg muscle toward the jump shoot ability on basketball athlete at Sport Science Faculty of Padang State University. The type of the research is correlational. The population and the sample of this research are the basketball athletes at Sport Science Faculty of Padang State University. Then, the data of this research was analyzed by using product moment correlation. The results of this study are: (1) there are contributions of explosive power of the leg muscles toward the jump shoot ability of the basketball athletes at Sport Science Faculty of Padang State University $r=0.92$. (2) there is contribution of balance toward the jump shoot ability of basketball athletes at Sport Science Faculty of Padang State University $r=0.90$. (3) there is simultaneous contribution of the power of the leg muscles and balance toward the ability of jump shoot of the athletes at Sport Science Faculty of Padang State University $r=0.87$. Based on the result of this research, it can be concluded that there is a significant contribution from the balance of explosive power of leg muscle toward the basketball athletes' ability of jump shoot at Sport Science Faculty of Padang State University.
\end{abstract}

Keywords: Leg muscles, jump shoot, athletes

\section{INTRODUCTION}

Basketball is an increasingly popular sport among societies, especially students. This is because basketball is a sport that can be done by any groups of societies. There are many benefits that can be gained from this sport, either physical, mental, or social benefits. In addition, the increasing number of competitions and tournaments either the local ones, e.g. NBL (National Basketball League), LIMA (Student League), DBL (Deteksi Basketball League), or the international ones, e.g. NBA (National Basketball Association), FIBA (Federation International Basketball), World Cup, and so forth, indirectly influences and improves the development of basketball especially in Indonesia.

At the faculty of sport science (FIK) UNP, basketball, up to present, has not made significant progress in the national arena. This can be seen from the lack of achievements achieved in various national events, e.g. Pekan Olahraga Mahasiswa Nasional (POMNAS). The indicator is the basketball medal achievement on POMNAS event; basketball has never contributed a medal (BAPOMI SUMBAR 2009).

From the aforementioned data, there comes a question, "why hasn't basketball at FIK UNP gained achievements at regional and national levels?" The achievements can be achieved if the athletes practice maximally by using the right training methods. Moreover, the coordination between trainer and administrator needs to be improved in an effort to promote the basketball at FIK UNP.

Bompa (1994) states that all athletic programs should incorporate the fundamental factors of training, i.e. physical, technical, tactical, psychological and theoretical training. In other words, in an attempt to gain achievements, we have to pay attention to the fundamental factors in the exercise: physique, techniques, tactics, mentality and exercise theories. The achievements can be achieved if the athletes perform the exercises in accordance with the programs that are arranged systematically.

Shooting is a basic technique that all basketball players should master. The types of basketball shoot, according to a book published by FIBA (1998) entitled "Basket Ball for Everyone", are: set shoot, lay-up shoot, underline shoot, jump shoot, hook shoot, dunking, and reverse lay-up. Jump shoot is a basic shooting technique that is often used by every player to earn points on the match. Jump shoot can be done by any players in any positions. Usually, in a basketball team, 
the ability of jump shoot is only obtained by a player characterized as a shooter; however, in today's reality the ability of jump shoot can be done by every player in the team because the win of a match is determined by the number of points obtained through the shots made by the team.

A basketball player is supposed to be able to master jump shoot technique well because jump shoot has advantages compared to other shooting types. One of the advantages of jump shoot is that a player can avoid a block from the opponent when shooting since (s)he releases the ball at the highest point of the jump. It is unlike the set shoot in which the ball is released at the same time as the jump. The other advantage of jump shoot is that a player can control the power in the air to get better shot accuracy.

Technically, jump shoot is easy to do because the shot consists of several stages / phases of movement: jumping, hand motion in shooting, eye focus on the target, releasing the ball and further movements. In this case, all the movement phases are a well-coordinated sequence.

From the observation in the field on the basis of statistics obtained, the basketball athletes at FIK UNP, in shooting particularly doing jump shoot, had difficulty in generating points so many opportunities to make points were uselessly wasted. In addition, the difficulty in doing jump shoot often occurred. The basketball athletes at FIK UNP, to make points, relied more on the transition of defense-to-offense or fastbreak and lay-up shoot. The basketball athletes at FIK UNP had difficulty in dealing with the opponents who had a good offense-to-defense transition.

In other words, the basketball athletes tend to do lay-up shoot instead of jump shoot because they face difficulties in doing jump shoot. The reasons why the players frequently fail doing jump shoot need to be investigated and unraveled.

In doing jump shoot, a couch needs to be aware of athletes' physical condition such as strength, speed, agility, balance, accuracy, endurance, liveliness, coordination, and the muscle power. Thus, possessing these physical conditions enables the players to do jump shoot.

Based on those aforementioned factors, it is imperative to do a study to figure out and empirically reveal the contribution of the leg muscles power and the balance to basketball athletes' ability to do jump shoot.

\section{METHOD}

This study aimed to find out the contribution of leg muscles power and the balance to basketball athletes' ability to do jump shoot. Based on the above-mentioned explanation, this study was a correlational study. Besides, the samples of this study were 20 athletes at Sport Science Faculty at UNP.
The instruments used were as follows: 1) jump shoot ability test Speed Spot Shooting Test (Margareth J. Safrit, 1995:558-559) was used to measure the athletes' jump shoot ability, 2) leg muscles power test to measure the power of leg muscles, vertical jump shoot was used. It was done by measuring the height difference between Raihan's standing position and Raihan's jumping position, 3) the balance test Modified Bass Test of Dynamic Balance was used to measure the athletes' balance.

\section{RESULTS AND DISCUSSION}

Based on data analysis, the value of $r(0.92)$ showed that the power of leg muscles contributed to the athletes' jump shoot ability at Sport Science Faculty Universitas Negeri Padang. Similarly, the result also revealed that the balance contributed to the athletes' jump shoot ability which was indicated by $r$ value (0.90). Furthermore, the power of leg muscles and balance simultaneously gave the contribution to the athletes' jump ability which was seen from $r$ value (0.87).

Based on these findings, it is concluded that to have good jump shoot ability, an athlete is required to have leg muscle power and good balance. It is a requisite because in doing the jump shoot an athlete needs to jump as high as possible and at the same time he must keep the balance in order to have good shoot.

\section{CONCLUSION}

Based on the findings of this study, it is concluded that: 1) There was contribution of leg muscles power to the basketball athletes' jump shoot ability at Sport Science Faculty Universitas Negeri Padang, 2) There was contribution of balance to the basketball athletes' jump shoot ability at Sport Science Faculty Universitas Negeri Padang, 3) There was simultaneous contribution of leg muscles power and balance to the basketball athletes' jump shoot ability at Sport Science Faculty Universitas Negeri Padang

\section{REFERENCES}

[1] Bompa, Theory and Methodology of Training, (USA: Human Kinetics, 1994)

[2] Danny Kosasih, Fundamental Basketball: First Step to Win, (Semarang: Karangturi Media, 2008)

[3] Dave Bellomo, Kettlebell Training For Athletes, (USA:Mc Graw-Hill Company, 2010)

[4] Dave Hopla, Better Basketball Shooting, (USA: Human Kinetics, 2013)

[5] Federation International Basketball Association, Basketball For Everyone, (USA: FIBA 1998)

[6] Perbasi. Potret Bola Basket Indonesia. (Jakarta: Perbasi,2001)

[7] Phillips, D. Allen \& Hornak, James E, Measurement and Evaluation in Physical 
Education, (Canada: John Wiley \& Sons Inc, 1979)

[8] Sally Goddard Blythe, Attention, Balance and Coordination, (USA:Blackwell Publishing, 2009)
[9] Tudor O Bompa, Periodization, (USA:Human Kinetics, 2009) 